\title{
Optimization of the HS-SPME-GC/MS technique for determining volatile compounds in red wines made from Isabel grapes (Vitis labrusca)
}

\author{
Narciza Maria de Oliveira ARCANJO ${ }^{1 \star}$, Taliana Kênia Alvez BEZERRA ${ }^{1}$, \\ Flávio Luís Honorato da SILVA ${ }^{1}$, Marta Suely MADRUGA ${ }^{1}$
}

\begin{abstract}
Brazilian wine production is characterized by Vitis labrusca grape varieties, especially the economically important Isabel cultivar, with over $80 \%$ of its production destined for table wine production. The objective of this study was to optimize and validate the conditions for extracting volatile compounds from wine with the solid-phase microextraction technique, using the response surface method. Based on the response surface analysis, it can be concluded that the central point values maximize the process of extracting volatile compounds from wine, i.e., an equilibrium time of 15 minutes, an extraction time of 35 minutes, and an extraction temperature of $30^{\circ} \mathrm{C}$. Esters were the most numerous compounds found under these extraction conditions, indicating that wines made from Isabel cultivar grapes are characterized by compounds that confer a fruity aroma; this finding corroborates the scientific literature.
\end{abstract}

Keywods: method; factorial design; grape; validation.

Practical Application: Application of factorial design to optimize the extraction conditions of volatile compounds.

\section{Introduction}

In Brazil, wine production from American grapes, especially the species Vitis labrusca, exceeds wine production from Vitis vinifera grapes. Wines made from Vitis labrusca, according to Brazilian legislation, are known as "table wines" and represent more than $80 \%$ of Brazil's total production volume (Biasoto et al., 2014; Brasil, 2014; Castilhos et al., 2013).

The Isabel cultivar is one of the main Vitis labrusca cultivars used as a basic raw material for making table wines in Brazil. Its cultivation and expansion is a result of its easy adaptation, disease resistance, and high productivity. Wine made from this cultivar has aroma, and sweet, fruity taste also is consumed in large quantities by diverse population segments because of its low cost (Nixdorf \& Hermosín-Gutiérrez, 2010; Rombaldi et al., 2004).

The volatile composition of wines directly affects their characteristics, especially the aroma, which is the product of a biochemical and technological sequence that links wine quality and origin (Jiang et al., 2013; Noguerol-Pato et al., 2009; Zhang et al., 2011). Wine aroma composition analysis is complex because of the different classes, levels, reactivities and heat sensitivities of its constituents (Bonino et al., 2003; Welke et al., 2012).

Volatile compounds can be extracted from wines using various techniques to profile and quantify these compounds. Solid-phase microextraction (SPME) is currently one of the most commonly used techniques; it is fast and inexpensive, does not require the use of solvents, is able to detect low concentrations, and requires little sample manipulation (Antalick et al., 2010; Canuti et al., 2009; Jelén et al., 2012; Oliveira \& Mamede, 2012; Sagratini et al., 2012; Slaghenaufi et al., 2014).
The SPME is technique allows the acquisition of interesting results when gas chromatography is combined with mass spectrometric detection, making the simultaneous analysis of tens or hundreds of volatile compounds possible, but this a technique that must be optimized (Dórea et al., 2008; Jelén et al., 2012).

The SPME technique is currently used to analyse volatiles compounds from food and beverages. For the volatile profile of wines different fibres should be used, since the aroma of wine is very complex and presenting a great diversity of compounds. According to the scientific literature two polymer films are the most efficient for extracting volatile compounds from wines; i.e. PDMS/CAR/DVB-polydimethylsiloxane-carboxen-divinylbenzene and CAR/PDMS-carboxen-polydimethylsiloxane (Barros et al., 2012; Noguerol-Pato et al., 2009; Petrozziello et al., 2012; Sagratini et al., 2012; Tao et al., 2008; Weldegergis et al., 2011; Welke et al., 2012, 2014; Zhang et al., 2011).

Factorial design associated with the response surface analysis has been used as an important and simple statistical method in studies that examine many variables. It makes organized design and performance of the minimum experiments necessary possible, allowing interpretation of the effect of the variables on an analytical response, saving time and financial resources (Silva et al., 2008; Pereira-Filho et al., 2002). This methodology is also used to adjust and to analyze problems concerning the influence of some independent variables on some response variables, thus aiming to optimize those response variables (Gomes \& Costa, 2004).

This study aimed to optimize and validate the conditions for extracting volatile compounds from wine using SPME and 
the response surface method. The results may contribute to the identification of the aroma profile of wines made with Isabel grapes for future studies, as studies on the volatile compositions of these wines are still scarce.

\section{Materials and methods}

\subsection{Optimizing the SPME method}

Table red wine from the 2012 harvest acquired from the João Pessoa, Paraíba, Brazil market was used. The conditions for extracting the volatile compounds were defined using an RCCD, and the results were evaluated using the response surface method. The following steps were used to optimize the volatile compound extraction process.

\section{Selecting the SPME fiber and defining the variables}

The films polydimethylsiloxane-carboxen-divinylbenzene (PDMS/CAR/DVB) and carboxen-polydimethylsiloxane (CAR/PDMS) were obtained from Supelco (Bellefonte, Pennsylvania, USA). For the extraction, $30 \mathrm{~mL}$ of wine was added to a $100-\mathrm{mL}$ glass flask fitted with a septum screw cap. The extraction was performed in a water bath with internal magnetic stirring at $40{ }^{\circ} \mathrm{C}$, allowing the reaction to reach equilibrium for 15 minutes and then exposing the film for 30 minutes.

The levels of the input variables equilibrium time $\left(\mathrm{t}_{\mathrm{eq}}\right)$, extraction time $\left(\mathrm{t}_{\mathrm{ex}}\right)$, and extraction temperature (T) (Table 1).

An RCCD was used to test the effect of the three input variables $-T, t_{e q}$ and $t_{e x}$ - to define the optimal ranges of the process operation. The experiment followed a $2^{3}$ factorial design with eight trials, plus six axial points and three central points (CPs), totaling seventeen experiments (RCCD). The empirical model of the non-linear regression of the experimental data comprises a second-order polynomial, presented in Equation 1, where $\mathrm{Y}$ is the response function, $\mathrm{t}_{\mathrm{eq}}, \mathrm{t}_{\mathrm{ex}}$, and $\mathrm{T}_{\mathrm{ex}}$ are the variables studied, $\beta$ represents the coefficients of the model, and $\varepsilon$ is the experimental error.

$$
\begin{aligned}
& \mathbf{Y}=\beta 0+\beta 1 \text { teq }+\beta 2 \text { tex }+\beta 3 \text { Tex }+\beta 4 \text { teq }^{2}+ \\
& \beta 5 \text { tex }^{2}+\beta 6 \mathrm{~T}^{2}+\beta \text { teq.tex }+\beta 8 \text { teq.T }+\beta 9 \text { tex.T }+\varepsilon
\end{aligned}
$$

\subsection{Statistical analysis}

The responses (dependent variables) of the experiment performed were the TN (Total number of peaks), TA (Total area of the chromatogram) and area of the IA (Isoamyl acetate) compound. Residual analysis was performed at the $95 \%$ confidence level $(p<0.05)$, which comprised the significance test of the fitted model based on analysis of variance (ANOVA) using the statistical program Statistica 5.0 (Statsoft, 2001). After defining the optimal volatile compound extraction conditions, the method was validated; then, the sample was extracted and injected in triplicate.

\subsection{Chromatographic analyses for identifying the volatile compounds in red wine}

GC separation of volatiles collected by SPME technique was carried out on a VF-5 ms low bleed/MS fused-silica capillary column (5\% phenyl/95\% PDMS, $60 \mathrm{~m} 0.25 \mathrm{~mm}$ I.D., $0.25 \mathrm{~lm}$ film thickness, Varian). The temperature program employed was $5 \mathrm{~min}$ at $35 \mathrm{C}$, a ramp of $3 \mathrm{C} / \mathrm{min}$ to $240 \mathrm{C}$, and held for $5 \mathrm{~min}$. Helium was used as the carrier gas. The Varian Saturn 2000R mass spectrometer was operated in electron impact mode with a source temperature of $200 \mathrm{C}$, an ionising voltage of $70 \mathrm{eV}$, and a scan range from $\mathrm{m} / \mathrm{z} 29$ to $\mathrm{m} / \mathrm{z} 350$ at 3.33 scans/ $\mathrm{s}$. The SPME data were acquired and analysed using the GC/SW spectra database. Identification of the compounds was based on the comparison of their mass spectra with spectra from authentic compounds previously analysed, spectra from the NIST/EPA/NIH Mass Spectral Database (Version 1.7), or spectra published elsewhere. To confirm the identification, the linear retention index (LRI) was calculated for each volatile compound using the retention times of a homologous series of C7-C30 n-alkanes, and by comparing the LRI with those of authentic compounds analysed under similar conditions.

\section{Results and discussion}

\subsection{SPME fiber choice}

A total of 42 volatile compounds were identified in commercial red wine as follows: 19 esters, 8 terpenes, 6 alcohols, and 9 compounds of other classes, including aldehydes, ketones, acids, and amines. The PDMS/CAR/DVB (41 compounds identified) fiber exhibited higher performance than the CAR/PDMS (19 compounds identified) fiber and was selected for use in the other analysis steps of volatiles in wine made from Isabel grapes. The PDMS/CAR/DVB fiber is considered to have intermediate polarity, and previous reports have demonstrated its efficacy in various food matrices, with a higher performance compared to that of other types of polymer films (Welke et al., 2012). This is due to the fiber having three distinct layers, each with a different composition, thus increasing the sorptive capacity of the compounds (Zhang et al., 2011).

\subsection{Optimization of the conditions for extracting volatile compounds from wine}

The RCCD indicated an effect of the independent variables on the response variable values of the process: the total number of peaks (TN), total area of the chromatogram (TA), and area of the

\begin{tabular}{|c|c|c|c|c|c|}
\hline Factors & $-a$ & -1 & 0 & +1 & $+a$ \\
\hline Equilibrium time $\left(\mathrm{t}_{\mathrm{eq}}\right)$ & $7 \mathrm{~min}$ & $10 \mathrm{~min}$ & $15 \mathrm{~min}$ & $20 \mathrm{~min}$ & $23 \mathrm{~min}$ \\
\hline Extraction time $\left(\mathrm{t}_{\mathrm{ex}}\right)$ & $10 \mathrm{~min}$ & $20 \mathrm{~min}$ & $35 \mathrm{~min}$ & $50 \mathrm{~min}$ & $60 \mathrm{~min}$ \\
\hline Temperature $(\mathrm{T})$ & $13^{\circ} \mathrm{C}$ & $20^{\circ} \mathrm{C}$ & $30^{\circ} \mathrm{C}$ & $40^{\circ} \mathrm{C}$ & $47^{\circ} \mathrm{C}$ \\
\hline
\end{tabular}

Table 1. Variables and actual and coded levels employed in the rotatable central composite design (RCCD) to optimize the extraction conditions.

Applying the design method to optimize the volatile compound extraction conditions. 
isoamyl acetate (IA) compound. TN and TA are important variables for determining the optimized parameters for chromatographic analysis; the higher the number of peaks that are detected, the higher the number of compounds captured by the fiber is, and the greater the total area of the chromatogram, the higher the concentration of the compounds and the number of peaks will likely be. Esters comprised the largest class of compounds identified in the chromatograms, and among these, IA exhibited expressive area values. Studies have found that IA confers a fruity aroma to wines (Antalick et al., 2010; Jiang et al., 2013). Table 2 presents a design matrix with the responses obtained in the assays performed with combinations of the levels studied.

According to the analysis of variance (ANOVA), there was variation due to the regression parameters, and it was only possible to construct a significant $(p<0.05)$ model for the IA response, where the coefficient of determination $\left(\mathrm{R}^{2}\right)$ in the experimental model was 0.9785 , and the $\mathrm{F}_{\text {calculated }} / \mathrm{F}_{\text {tabulated }}$ ratio was higher than 1 . In contrast, the estimated effects for the TN and TA responses obtained $\mathrm{R}^{2}$ values $<0.6$, indicating that only $<60 \%$ of the variability in response can be explained by the non-linear regression of the experimental data. The $\mathrm{F}_{\text {calculated }} / \mathrm{F}_{\text {tabulated }}$ ratio values were lower than 1 , which is considered unsatisfactory for obtaining a valid predictive model (Rodrigues \& Iemma, 2009).

According to Araújo et al. (2013), the Pareto diagram (Figure 1) rapidly and clearly reveals the significant effects (Araújo et al., 2013). The negative and quadratic equilibrium time, extraction time, and extraction temperature contributed the most in detecting the highest TN, TA, and area of the IA compound. Thus, the mathematical model with significant $(p<0.05)$ coefficients can be described by Equation 2 .

Isoamyl acetate $=1578380+84061 \mathrm{~T}-$
To plot the response surface (Figure 2), the extraction temperature was fixed at the 0 level $\left(30^{\circ} \mathrm{C}\right)$, as it was the variable with the highest significant effect on the response studied. The region with the best response values (IA) was located between the equilibrium time of 15 minutes and the extraction time of 35 minutes.

\subsection{Validating the method optimization of the extraction conditions}

Because the variables at the central point generate the highest IA compound area value, the volatile compounds were extracted from the wine in triplicate, using the following equilibrium time, extraction time, and extraction temperature values at the central points to validate the method: 15 minutes, 35 minutes, and $30^{\circ} \mathrm{C}$, respectively.

The experimental data and model for the IA compound area values are presented in Table 2 . The values at the central point for the independent variables were used in the model equation (Equation 2) to obtain the modeled value of the response under study.

Table 3 shows that the difference between the mean value of three replicates when conducting the analysis with the independent variable values at the central point and the non-linear regression model value of the experimental data from the experimental design (Equation 2) is 5\%; this finding is considered a low difference, as it is below $10 \%$ (Rodrigues \& Iemma, 2009).

\subsection{Characterizing the volatile compounds identified in red wine made from the Isabel cultivar}

A total of 33 compounds were identified in the red wine analyzed after SPME extraction using the optimized parameters, i.e., operating with the variables set at a $30{ }^{\circ} \mathrm{C}$ extraction

Table 2. Design matrix - rotatable central composite design (RCCD), with actual and coded levels, including the response variables.

\begin{tabular}{|c|c|c|c|c|c|c|}
\hline \multirow{2}{*}{ ASSAYS } & \multicolumn{3}{|c|}{ Independent variables } & \multicolumn{3}{|c|}{ Responses } \\
\hline & $\mathrm{t}_{\mathrm{eq}}(\mathrm{min})$ & $\mathrm{t}_{\mathrm{ex}}(\min )$ & $\mathrm{T}\left({ }^{\circ} \mathrm{C}\right)$ & $\mathrm{TN}^{\mathrm{a}}$ & $\mathrm{TA}^{\mathrm{b}}$ & $\mathrm{IA}^{\mathrm{c}}$ \\
\hline 1 & $-(10)$ & $-(20)$ & $-(20)$ & 30 & $5.66 \mathrm{E}+07$ & $1.37 \mathrm{E}+05$ \\
\hline 2 & $+(20)$ & $-(20)$ & $-(20)$ & 29 & $4.56 \mathrm{E}+07$ & $1.49 \mathrm{E}+05$ \\
\hline 4 & $+(20)$ & $+(50)$ & $-(20)$ & 28 & $3.42 \mathrm{E}+07$ & $7.48 \mathrm{E}+04$ \\
\hline 5 & $-(10)$ & $-(20)$ & $+(40)$ & 25 & $2.97 \mathrm{E}+07$ & $1.71 \mathrm{E}+05$ \\
\hline 8 & $+(20)$ & $+(50)$ & $+(40)$ & 24 & $7.56 \mathrm{E}+07$ & $1.31 \mathrm{E}+05$ \\
\hline 9 & $-\alpha(7)$ & $0(35)$ & $0(30)$ & 22 & $5.39 \mathrm{E}+07$ & $1.49 \mathrm{E}+05$ \\
\hline 10 & $+a(23)$ & $0(35)$ & $0(30)$ & 23 & $8.90 \mathrm{E}+07$ & $1.64 \mathrm{E}+05$ \\
\hline 11 & $0(15)$ & $-a(10)$ & $0(30)$ & 24 & $4.88 \mathrm{E}+07$ & $1.74 \mathrm{E}+05$ \\
\hline 12 & $0(15)$ & $+a(60)$ & $0(30)$ & 22 & $6.36 \mathrm{E}+07$ & $1.69 \mathrm{E}+05$ \\
\hline 16 & $0(15)$ & $0(35)$ & $0(30)$ & 33 & $5.71 \mathrm{E}+07$ & $1.58 \mathrm{E}+06$ \\
\hline 17 & $0(15)$ & $0(35)$ & $0(30)$ & 34 & $5.71 \mathrm{E}+07$ & $1.58 \mathrm{E}+06$ \\
\hline
\end{tabular}

${ }^{a}$ Total number of peaks. ${ }^{b}$ Total area of peaks. ${ }^{c}$ Area of the isoamyl acetate compound. 


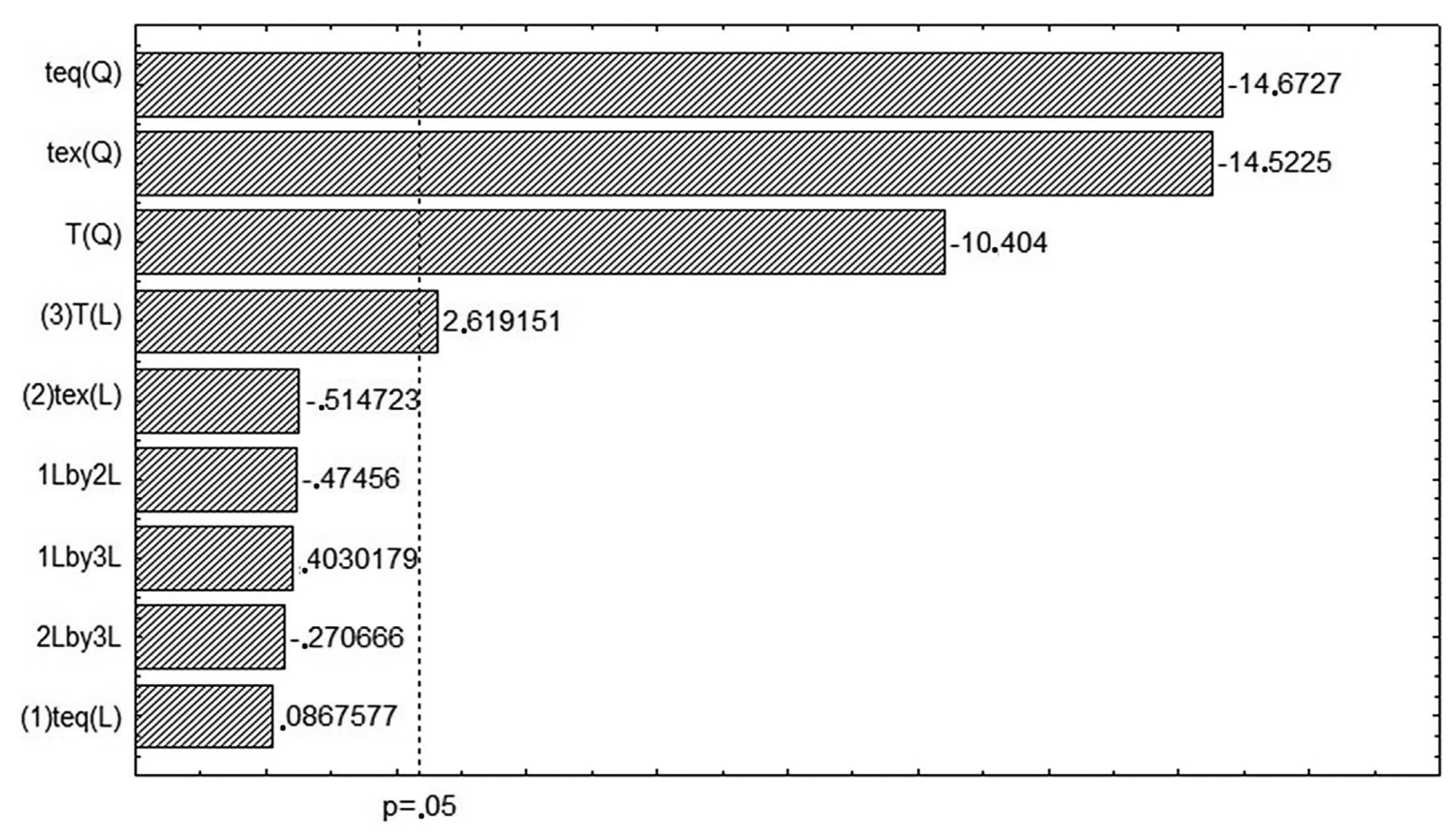

Figure 1. Estimation of the linear and quadratic effects of the independent variables equilibrium time $\left(t_{e q}\right)$, extraction time $\left(t_{e x}\right)$, and extraction temperature $(\mathrm{T})$ on the response variables total number of peaks (TN), total area of the peaks (TA), and area of the isoamyl acetate (IA) compound.

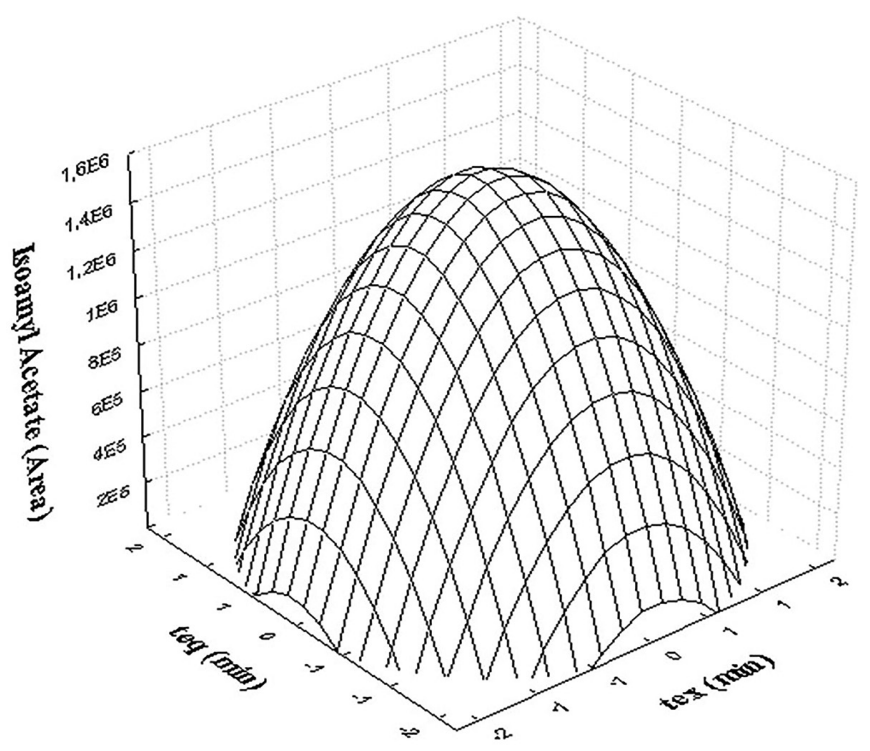

Figure 2. Effect of the response variable (isoamyl acetate) with the temperature $\left(30^{\circ} \mathrm{C}\right)$ fixed at the central point.

Table 3. Experimental values and those of the model for the isoamyl acetate response variable.

\begin{tabular}{cc}
\hline Experimental value $^{\mathrm{a}}$ & Model value $^{\mathrm{b}}$ \\
\hline $1.50 \mathrm{E}+06 \pm 5.10 \mathrm{E}+04$ & $1.58 \mathrm{E}+06$ \\
\hline
\end{tabular}

${ }^{a}$ Mean \pm standard deviation of three replicates of the volatile compound extraction analysis using the equilibrium time, extraction time, and extraction temperature values at the central points. ${ }^{b}$ Value of the response model with the input (independent) variables fixed at the central point. temperature, a 15-minute equilibrium time, and a 35-minute extraction time: 18 esters, 6 alcohols, 4 terpenes, 3 ketones, 1 amine, and 1 acid (Table 4 ).

In the present study, esters were the most numerous compounds in the wines and included ethyl propanoate, ethyl hexanoate, ethyl octanoate and ethyl decanoate, diethyl succinate, and IA. Esters are wine volatiles that contribute to its fruity aroma (Welke et al., 2012) and are mainly derived from the fermentation process.

The alcohols identified in the wine may have been produced from the synthesis of secondary products of yeast metabolism (Fariña et al., 2014). This compound class most likely positively contributed to the alcoholic aroma (1-propanol and 1-butanol) and floral aroma (phenethyl alcohol) of the red wines made from Isabel grapes (Jiang et al., 2013).

Terpenes that belong to secondary plant constituents are biologically synthesized through the cytosolic mevalonic-acid pathway from three acetyl-CoA molecules or through the pyruvate and glyceraldehyde-3-phosphate pathway (Robinson et al., 2014). In the wine analyzed, the terpenes identified confer a citrus and floral aroma (Jiang et al., 2013).

Among the ketones, $\beta$-ionone had the highest area value and provides odor is associated with "pink", "violet" and "vinegar" aromas (Azevêdo et al., 2007). According to Azevêdo et al. (2007), they can also be responsible for the product's sensory quality, thus being negative or positive markers for wine, depending on the concentration of these compounds.

One amine and one acid were also found in the wine, and their presence may have been affected by the winemaking process. 
Table 4. Volatile compounds identified in the analysis of red wine made from Isabel grapes.

\begin{tabular}{|c|c|c|c|c|}
\hline Number & Compound & Area $^{\mathrm{a}}$ & $\mathrm{LRI}^{\mathrm{b}}$ & $\mathrm{ID}^{\mathrm{c}}$ \\
\hline \multicolumn{5}{|l|}{ Alcohols } \\
\hline 2 & 1-Butanol & $5.09 \mathrm{E}+05$ & $<600$ & A \\
\hline 3 & 1-Propanol & $6.62 \mathrm{E}+05$ & $<600$ & A \\
\hline 7 & 2-Methyl-1-butanol & $7.53 \mathrm{E}+05$ & 757 & $\mathrm{~A} / \mathrm{B}$ \\
\hline 24 & Phenethyl alcohol & $4.22 \mathrm{E}+06$ & 1140 & $\mathrm{~A} / \mathrm{B}$ \\
\hline 25 & 1-Nonanol & $4.79 \mathrm{E}+05$ & 1186 & $\mathrm{~A} / \mathrm{B}$ \\
\hline \multicolumn{5}{|l|}{ Esters } \\
\hline 6 & Propanoic acid, ethyl ester (ethyl propanoate) & $1.46 \mathrm{E}+06$ & 718 & $\mathrm{~A} / \mathrm{B}$ \\
\hline 8 & Propanoic acid, 2-methyl-, ethyl ester (ethyl isobutyrate) & $1.53 \mathrm{E}+05$ & 764 & $\mathrm{~A} / \mathrm{B}$ \\
\hline 9 & Acetic acid, 2-methylpropyl ester (isobutyl acetate) & $1.87 \mathrm{E}+05$ & 780 & $\mathrm{~A} / \mathrm{B}$ \\
\hline 11 & Butanoic acid, ethyl ester (ethyl butyrate) & $2.67 \mathrm{E}+05$ & 807 & $\mathrm{~A} / \mathrm{B}$ \\
\hline 12 & 2-Butenoic acid, ethyl ester, (E)- (trans-ethyl 2-butenoate) & $8.15 \mathrm{E}+04$ & 853 & $\mathrm{~A} / \mathrm{B}$ \\
\hline 13 & Butanoic acid, 2-methyl-, ethyl ester (ethyl 2- methylbutanoate) & $7.90 \mathrm{E}+04$ & 855 & $\mathrm{~A} / \mathrm{B}$ \\
\hline 14 & Butanoic acid, 3-methyl-, ethyl ester (ethyl 3- methylbutanoate) & $1.18 \mathrm{E}+05$ & 859 & $\mathrm{~A} / \mathrm{B}$ \\
\hline 15 & 1-Butanol, 3-methyl-, acetate (isoamyl acetate) & $1.50 \mathrm{E}+06$ & 883 & $\mathrm{~A} / \mathrm{B}$ \\
\hline 16 & Ethyl 2-methylbutyl & $6.05 \mathrm{E}+05$ & 884 & $\mathrm{~A} / \mathrm{B}$ \\
\hline 17 & Hexanoic acid, ethyl ester (ethyl hexanoate) & $2.67 \mathrm{E}+06$ & 1006 & $\mathrm{~A} / \mathrm{B}$ \\
\hline 18 & 2-methyl-1 pentanol acetate & $3.85 \mathrm{E}+04$ & 1019 & $\mathrm{~A} / \mathrm{B}$ \\
\hline 20 & Propanoic acid, 2-hydroxy-, 3-methylbutyl ester (Isoamyl lactate) & $9.19 \mathrm{E}+04$ & 1080 & $\mathrm{~A} / \mathrm{B}$ \\
\hline 22 & Heptanoic acid, ethyl ester (ethyl heptanoate) & $1.79 \mathrm{E}+05$ & 1104 & $\mathrm{~A} / \mathrm{B}$ \\
\hline 26 & Butanedioic acid, diethyl ester (diethyl succinate) & $4.05 \mathrm{E}+06$ & 1191 & $\mathrm{~A} / \mathrm{B}$ \\
\hline 27 & Octanoic acid, ethyl ester (ethyl octanoate) & $1.41 \mathrm{E}+07$ & 1199 & $\mathrm{~A} / \mathrm{B}$ \\
\hline 31 & Decanoic acid, ethyl ester (ethyl decanoate) & $1.47 \mathrm{E}+06$ & 1402 & $\mathrm{~A} / \mathrm{B}$ \\
\hline 32 & Dodecanoic acid, ethyl ester (ethyl dodecanoate) & $1.38 \mathrm{E}+05$ & 1601 & $\mathrm{~A} / \mathrm{B}$ \\
\hline 33 & Hexadecanoic acid, ethyl ester (ethyl hexadecanoate) & $1.57 \mathrm{E}+05$ & 2000 & $\mathrm{~A} / \mathrm{B}$ \\
\hline \multicolumn{5}{|l|}{ Terpenes } \\
\hline 8 & a-Terpinyl acetate & $2.99 \mathrm{E}+06$ & 1214 & $\mathrm{~A} / \mathrm{B}$ \\
\hline 19 & Limonene & $8.66 \mathrm{E}+04$ & 1040 & $\mathrm{~A} / \mathrm{B}$ \\
\hline 21 & Terpinolene & $1.13 \mathrm{E}+05$ & 1097 & $\mathrm{~A} / \mathrm{B}$ \\
\hline 23 & Linalool & $4.53 \mathrm{E}+06$ & 1113 & $\mathrm{~A} / \mathrm{B}$ \\
\hline 29 & $\alpha$-Terpineol & $5.46 \mathrm{E}+05$ & 1268 & $\mathrm{~A} / \mathrm{B}$ \\
\hline \multicolumn{5}{|l|}{ Ketones } \\
\hline 4 & Acetal & $5.06 \mathrm{E}+03$ & $<600$ & A \\
\hline 10 & 3,2-Heptanone & $8.99 \mathrm{E}+04$ & 795 & $\mathrm{~A} / \mathrm{B}$ \\
\hline 30 & $\beta$-Ionone & $2.17 \mathrm{E}+06$ & 1303 & $\mathrm{~A} / \mathrm{B}$ \\
\hline \multicolumn{5}{|l|}{ Amine } \\
\hline 1 & Ethylamine & $3.74 \mathrm{E}+05$ & $<600$ & A \\
\hline \multicolumn{5}{|l|}{ Acid } \\
\hline 5 & Thioacetic acid & $4.14 \mathrm{E}+06$ & 702 & $\mathrm{~A} / \mathrm{B}$ \\
\hline
\end{tabular}

${ }^{a}$ Area values of each compound. ${ }^{b}$ Linear retention indices. ${ }^{c} \mathrm{~A}$, mass spectrum actaAO6815nd LRI according to those of a compound that occurred in the VF-5 MS column; B, mass spectrum according to the reference spectrum in the NIST/EPA/NIH mass spectrum database and LRI that corroborates the scientific literature (Jiang et al., 2013; Weldegergis et al., 2011).

\section{Conclusions}

When extracting the most volatile compounds, the SPME fiber with a PDMS/CAR/DVB coating exhibited a higher compound sorption capacity compared to the CAR/PDMS fiber. The experimental planning associated with response surface methodology using three independent variables allowed us to optimize the extraction process of volatiles from Isabel red wine, and also demonstrated that the experimental model displayed a value which was very close to the model deduced from real conditions. Therefore, the optimal conditions for extracting volatile compounds from red wine were an equilibrium time of
15 minutes, an extraction time of 35 minutes, and an extraction temperature of $30^{\circ} \mathrm{C}$. Under these extraction conditions, esters were the most common compound found, indicating that wines produced from Isabel cultivar grapes are characterized by compounds conferring fruity flavor; this finding is corroborated in the scientific literature.

\section{Acknowledgements}

The authors thank the National Council for Scientific and Technological Development (Conselho Nacional de Desenvolvimento Científico e Tecnológico - CNPq, Brazil) and the Coordination of 
Improvement of Higher Education Personnel (Coordenação de Aperfeiçoamento de Pessoal de Nível Superior - CAPES, Brazil) for providing financial assistance for this study.

\section{References}

Antalick, G., Perello, M.-C., \& Revel, G. (2010). Development, validation and application of a specific method for the quantitative determination of wine esters by headspace-solid-phase microextraction-gas chromatography-mass spectrometry. Food Chemistry, 121(4), 12361245. http://dx.doi.org/10.1016/j.foodchem.2010.01.011.

Araújo, W. O., Santos, D. M., \& Ascheri, D. P. R. (2013). Otimização do processo de extração de açúcares redutores da polpa de bauru. Revista Agrotecnologia, 4(2), 118-133.

Azevêdo, L. C., Reis, M. M., Silva, L. A., \& Andrade, J. B. (2007). Efeito da presença e concentração de compostos carbonílicos na qualidade de vinhos. Quimica Nova, 30(8), 1968-1975. http://dx.doi.org/10.1590/ S0100-40422007000800032.

Barros, E. P., Moreira, N., Pereira, G. E., Leite, S. G. F., Rezende, C. M., \& Pinho, P. G. (2012). Development and validation of automatic HS-SPME with a gas chromatography-ion trap/mass spectrometry method for analysis of volatiles in wines. Talanta, 101, 177-186. http://dx.doi.org/10.1016/j.talanta.2012.08.028. PMid:23158309.

Biasoto, A. C. T., Netto, F. M., Marques, E. J. N., \& Silva, M. A. A. P. (2014). Acceptability and preference drivers of red wines produced from Vitis labrusca and hybrid grapes. Food Research International, 62, 456-466. http://dx.doi.org/10.1016/j.foodres.2014.03.052.

Bonino, M., Schellino, R., Rizzi, C., Aigotti, R., Delfini, C., \& Baiocchi, C. (2003). Aroma compounds of an Italian wine (Ruché) by HS-SPME analysis coupled with GC-ITMS. Food Chemistry, 80(1), 125-133. http://dx.doi.org/10.1016/S0308-8146(02)00340-0.

Brasil. (2014, February 20). Decreto no 8.198, de 20 de fevereiro de 2014. Regulamenta a Lei no 7.678, de 8 de novembro de 1988, que dispõe sobre a produção, circulação e comercialização do vinho e derivados da uva e do vinho. Diário Oficial [da] República Federativa do Brasil.

Canuti, V., Conversano, M., Calzi, M. L., Heymann, H., Matthews, M., \& Ebeler, S. E. (2009). Headspace solid-phase microextraction-gas chromatography-mass spectrometry for profiling free volatile compounds in Cabernet Sauvignon grapes and wines. Journal of Chromatography. A, 1216(15), 3012-3022. http://dx.doi.org/10.1016/j. chroma.2009.01.104. PMid:19233370.

Castilhos, M. B. M., Conti e Silva, A. C., \& Del Bianchi, V. L. (2013). Evaluation of new red winemaking technologies through consumer liking. Ciência e Agrotecnologia, 7(2), 170-178. http://dx.doi. org/10.1590/S1413-70542013000200008.

Dórea, H. S., Gaujac, A., \& Navickiene, S. (2008). Microextração em fase sólida: aspectos termodinâmicos e cinéticos. Scientia plena, 4(7), 1-7.

Fariña, L., Villar, V., Ares, G., Carrau, F., Dellacassa, E., \& Boido, E. (2014). Volatile composition and aroma profile of Uruguayan Tannat wines. Food Research International, 69, 244-255. http://dx.doi. org/10.1016/j.foodres.2014.12.029.

Gomes, M. O., \& Costa, S. C. (2004). A utilização da análise de superfície de respostas na verificação da inflência dos parâmetros do processo de corte por plasma e ar comprimido. Revista Pesquisa e Desenvolvimento de Engenharia de Produção, 2, 54-68.

Jelén, H. H., Majcher, M., \& Dziadas, M. (2012). Microextraction techniques in the analysis of food flavour compounds: a review. Analytica Chimica Acta, 738, 13-26. http://dx.doi.org/10.1016/j. aca.2012.06.006. PMid:22790695.
Jiang, B., Xi, Z., Luo, M., \& Zhang, Z. (2013). Comparison on aroma compounds in Cabernet Sauvignon and Merlot wines from four wine grape-growing regions in China. Food Research International, 51(2), 482-489. http://dx.doi.org/10.1016/j.foodres.2013.01.001.

Nixdorf, S. L., \& Hermosín-Gutiérrez, I. (2010). Brazilian red wines made from the hybrid grape cultivar Isabel: Phenolic composition and antioxidant Capacity. Analytica Chimica Acta, 659(1-2), 208215. http://dx.doi.org/10.1016/j.aca.2009.11.058. PMid:20103126.

Noguerol-Pato, R., González-Barreiro, C., Cancho-Grande, B., \& SimalGándara, J. (2009). Quantitative determination and characterization of the main odorants of Mencía monovarietal red wines. Food Chemistry, 117(3), 473-484. http://dx.doi.org/10.1016/j.foodchem.2009.04.014.

Oliveira, L. C., \& Mamede, M. E. O. (2012). Sensory profile and contribution of major components of aroma in dry red wine quality. Vértices, 14(2), 7-25.

Pereira-Filho, E. R., Poppi, R. J., \& Arruda, M. A. Z. (2002). Emprego de planejamento fatorial para a otimização das temperaturas de pirólise e atomização de AL, CD, MO e PB por ETAAS. Quimica Nova, 25(2), 246-253. http://dx.doi.org/10.1590/S0100-40422002000200013.

Petrozziello, M., Borsa, D., Guaita, M., Gerbi, V., \& Bosso, A. (2012). Quantification by solid phase micro extraction and stable isotope dilution assay of norisoprenoid compounds in red wines obtained from Piedmont rare varieties. Food Chemistry, 135(4), 2483-2489. http://dx.doi.org/10.1016/j.foodchem.2012.07.082. PMid:22980832.

Robinson, A. L., Boss, P. K., Solomon, P. S., Trengove, R. D., Heymann, H., \& Ebeler, S. E. (2014). Origins of grape and wine aroma. Part1. Chemical components and vinicultural impacts. American Journal of Enology and Viticulture, 65(1), 1-24. http://dx.doi.org/10.5344/ ajev.2013.12070.

Rodrigues, M. I., \& Iemma, A. F. (2009). Planejamento de experimentos e otimização de processos. Campinas: Casa do Pão.

Rombaldi, C. V., Bergamasqui, M., Lucchetta, L., Zanuzo, M., \& Silva, J. A. (2004). Produtividade e qualidade de uva, cv. Isabel, em dois sistemas de produção. Revista Brasileira de Fruticultura, 26(1), 89-91. http://dx.doi.org/10.1590/S0100-29452004000100024.

Sagratini, G., Maggi, F., Caprioli, G., Cristalli, G., Ricciutelli, M., Torregiani, E., \& Vittori, S. (2012). Comparative study of aroma profile and phenolic content of Montepulciano monovarietal red wines from the Marches and Abruzzo regions of Italy using HSSPME-GC-MS and HPLC-MS. Food Chemistry, 132(3), 1592-1599. http://dx.doi.org/10.1016/j.foodchem.2011.11.108.

Silva, J. A., Damasceno, B. P. G. L., Silva, F. L. H., Madruga, M. S., \& Santana, D. P. (2008). Aplicação da metodologia de planejamento fatorial e análise de superfícies de resposta para otimização da fermentação alcoólica. Quimica Nova, 31(5), 1073-1077. http:// dx.doi.org/10.1590/S0100-40422008000500024.

Slaghenaufi, D., Perello, M. C., Marchand-Marion, S., Tempere, S., \& Revel, G. (2014). Quantitative solid phase microextraction - Gas chromatography mass spectrometry analysis of five megastigmatrienone isomers in aged wine. Analytica Chimica Acta, 813, 63-69. http:// dx.doi.org/10.1016/j.aca.2014.01.019. PMid:24528661.

Statsoft. (2001). Statistica data analysis system version 5.0. Tulsa: Statsoft Inc.

Tao, Y., Li, H., Wang, H., \& Zhang, L. (2008). Volatile compounds of young Cabernet Sauvignon red wine from Changli County (China). Journal of Food Composition and Analysis, 21(8), 689-694. http:// dx.doi.org/10.1016/j.jfca.2008.05.007.

Weldegergis, B. T., Villiers, A., McNeish, C., Seethapathy, S., Mostafa, A., Górecki, T., \& Crouch, A. M. (2011). Characterisation of volatile components of Pinotage wines using comprehensive two-dimensional 
gas chromatography coupled to time-of-flight mass spectrometry (GC × GC-TOFMS). Food Chemistry, 129(1), 188-199. http://dx.doi. org/10.1016/j.foodchem.2010.11.157.

Welke, J. E., Manfroi, V., Zanus, M., Lazarotto, M., \& Alcaraz Zini, C. (2012). Characterization of the volatile profile of Brazilian Merlot wines through comprehensive two dimensional gas chromatography time-of-flight mass spectrometric detection. Journal of Chromatography. A, 1226, 124-139. http://dx.doi.org/10.1016/j.chroma.2012.01.002. PMid:22277184.
Welke, J. E., Zanus, M., Lazzarotto, M., Pulgati, F. H., \& Zini, C. A. (2014). Main differences between volatiles of sparkling and base wines accessed through comprehensive two dimensional gas chromatography with time-of-flight mass spectrometric detection and chemometric tools. Food Chemistry, 164, 427-437. http://dx.doi. org/10.1016/j.foodchem.2014.05.025. PMid:24996354.

Zhang, M., Pan, Q., Guoliang, Y., \& Duan, C. (2011). Using headspace solid phase micro-extraction for analysis of aromatic compounds during alcoholic fermentation of red wine. Food Chemistry, 125(2), 743-749. http://dx.doi.org/10.1016/j.foodchem.2010.09.008. PMid:23140729. 